\title{
SAFETY AND QUALITY CONCERNS ASSOCIATED WITH FISH PRODUCTION
}

\author{
Edun, O.M. \\ Nigerian Institute for Oceanography and Marine Research/African Regional Aquaculture Centre, Buguma, Rivers State, \\ Nigeria
}

Copyright 2010, Fisheries Society of Nigeria.

This paper was prepared for presentation at the $25^{\text {th }}$ Annual International Conference and Exhibition in Administrative Staff College of Nigeria (ASCON), Topo-Badagry, Lagos, Nigeria, $25^{\text {th }}-29^{\text {th }}$ October, 2010

This paper was selected for presentation by an FISON Program Committee following review of information contained in an abstract submitted by the author(s). Contents of the paper, as presented, have not been reviewed by the Fisheries Society of Nigeria and are subject to correction by the author(s). The material, as presented, does not necessarily reflect any position of the Fisheries Society of Nigeria, its officers, or members. Papers presented at FISON meetings are subject to publication review by Editorial Committees of the Fisheries Society of Nigeria. Electronic reproduction, distribution, or storage of any part of this paper for commercial purposes without the written consent of the Fisheries Society of Nigeria is prohibited. Permission to reproduce in print is restricted to an abstract of not more than 300 words; reproduce in print is restricted to an abstract of not more than 300 words; illustrations may not be copied. The abstract must contain conspicuous acknowledgement of where and by whom the paper was presented. Write Librarian, Fisheries Society of Nigeria (FISON), P. O. Box 2607 Apapa,
Lagos.

\section{Abstract}

Global aquaculture production has grown rapidly over the last 50years. It is generally accepted that there is limited potential to increase traditional fisheries; consequently, increased aquaculture is required in order to maintain global per capita fish consumption at the present level. With nearly half of all fish eaten today coming from farms and some 12 million people dependent on fish farming for their daily income, ensuring that farmed fish products are safe to eat and of the highest possible quality is crucial. Most of the work reviewed in this article describes the safety and quality issues in farmed fish, implications for consumers and presents methods to improve product characteristics.

\section{Introduction}

The amount of fish supplied by farming has skyrocketed in recent years. In 1980 just 9 percent of the fish consumed by human beings came from aquaculture. Today 44 percent does (FAO, 2007).Responsible aquaculture is necessary to meeting the world's growing demand for fish and reducing pressure on stocks in the wild.
The increasing use of a range of technologies, chemicals and feed ingredients in both livestock and fish production poses a relatively new set of risks. Products such as antimicrobials, pesticides and a range of chemotherapeutants are often used with little idea either indirect or long-term risks (Little and Edwards 2003).

Prophylactic use of antibiotics and growth promoters in intensive fish feeds rival their use in the livestock industry. Similar problems, in terms of public health and consumer resistance have arisen (Little and Edwards 2003; EC 2001b). The development of genetically modified organisms, either as feeds of livestock and fish, or the animals themselves has been raised as both a moral and public health issue (Kleiter et al., 2001).

Producers and consumers in developed countries are not immune; however, as the increasing number of food scares indicates and the global food trade continues to expand. Pathogens can affect human health through both active and passive contact (Little and Edwards, 2003).

\section{CURRENT CONDITIONS AND PRACTICES IN AQUATIC ANIMAL PRODUCTION \\ Blood meal and blood products in fish feed}

The European Union permitted the use of blood meal from non- ruminants in fish feed (EC, 2003). This regulation is conditional on the products being based on pure pig or poultry blood. Pigs have a low retention of heavy metals and other undesirable substances such as dioxins. Today what is being used in most fish 
farm is ruminant (cow) blood, which may harbour a lot of parasites, pathogens and heavy metals.

\section{Veterinary drugs in fish feed and fish}

Antibiotics are commonly used in aquaculture worldwide to treat infection caused by a variety of bacterial pathogens of fish. They are commonly used as infeed medications or surface coated onto feed pellets and dispersed in water. The use of antibiotics in fish farming is associated with new hazards in fishery products that are not encountered in wild captured species (EC 2001c). The main hazards are antibiotic residues and the development of antimicrobial resistance in bacterial that may be transferred to consumers of farmed fish (EC, 2001b). Fish feed scare highlights challenges of aquaculture boom. More recently, several U.S.States banned certain catfish imports from overseas after tests on frozen fillets showed that some contain blacklisted antibiotics (FAO, 2007). These incidents illustrate the importance of ensuring product safety in fish farming.

\section{Pathogens in fish}

It must be emphasized that it is nearly always possible to detect a range of human pathogenic bacteria on any fish that has not received any bactericidal treatment. It is common for these pathogens that some growth in the fish products is required to produce disease in humans (EC, 2001b).In contrast, the presence of pathogens from the animal/human reservoir is a serious safety concern for products to be eaten without (further) cooking. Growth of pathogen in raw fish to be cooked is similarly of little safety concern. An example is Salmonella. Salmonella manifests itself clinically either as the enteric fever syndrome caused by typhoid or paratyphoid strains or as the nontyphoid dependent gastro-enteritis. Symptoms appearing 8-72 hours after exposure to the pathogen (D'House, 2000)

\section{Mycotoxin in fish feed and smoked fish}

Moulds perform a double role in feeds. Some are necessary to obtain different feeds. On the other occasions moulds act as spoilage microorganisms. The moulds themselves do not represent a hazard for consumers, but some secondary metabolites that they produce during their growth (mycotoxins) could be dangerous for human health. A lot of agricultural commodities are susceptible (Table 1) (De Meulanaer, 2007).

Table 1: $\quad$ Most Relevant mycotoxin - producing moulds and associated feed and diseases

\begin{tabular}{|c|c|c|c|}
\hline Mycotoxin & Mould & Associated & Disease \\
\hline Aflatoxin & $\begin{array}{l}\text { Aspergillus flavus } \\
\text { Aspergillus parasiticus } \\
\text { Aspergillus nomius }\end{array}$ & $\begin{array}{l}\text { Peanuts, corn, wheat, rice, } \\
\text { nuts, eggs, milk and } \\
\text { cheese }\end{array}$ & $\begin{array}{l}\text { Hepatotoxicity, intestinal tract } \\
\text { haemorrhage, kidney failure, } \\
\text { liver carcinogenesis }\end{array}$ \\
\hline Ochratoxin A & $\begin{array}{l}\text { Aspergillus ochraceus } \\
\text { Penicillium vindicatum }\end{array}$ & $\begin{array}{l}\text { Cereal grains, dry beans, } \\
\text { mould dry peanuts, cheese, } \\
\text { wine }\end{array}$ & $\begin{array}{l}\text { Nephropathy, teratogenic effect, } \\
\text { enteritis }\end{array}$ \\
\hline Ergot alkaloids & $\begin{array}{l}\text { Claviceps purpurea } \\
\text { Claviceps parspalli } \\
\text { Claviceps fusiformis }\end{array}$ & $\begin{array}{l}\text { Cereal grains, i.e. barley } \\
\text { and rye }\end{array}$ & $\begin{array}{l}\text { St. Anthony's fire. Gangrene } \\
\text { convulsions }\end{array}$ \\
\hline Cyclopigiagzonic acid & $\begin{array}{l}\text { Penicillum cyclopium } \\
\text { Aspergillus flavus }\end{array}$ & Corn, peanuts, cheese & $\begin{array}{l}\text { Intestinal haemorrhage, muscle } \\
\text { necrosis, oral lesions }\end{array}$ \\
\hline Patulin & $\begin{array}{l}\text { Aspergillus versicolor } \\
\text { Aspergillus tamari } \\
\text { Penicillium expansum } \\
\text { Byssochlamys nivea } \\
\text { Penicillium spp. } \\
\text { Aspergillus spp. }\end{array}$ & $\begin{array}{l}\text { Mouldy feed, rotten apples } \\
\text { and apple juice }\end{array}$ & $\begin{array}{l}\text { Oedemas, Haemorrhage, } \\
\text { paralysis of motor nerves, } \\
\text { convulsions, carcinogenesis }\end{array}$ \\
\hline Sterigmatocystin & Aspergillus versicolor & coffee, & Carcinogenesis, hepatotoxin \\
\hline
\end{tabular}


Trichottecenes

Zearalenone
Fusarium spp.

Fusarium graminearum wheat, Dutch cheeses

Corn, wheat, commercial Digestive disorders, dermatitis, cattle feed, mixed feed blood disorders

Corn, mouldy hay, Estrogenic effects, Antrophy of pelleted commercial feed testicles and ovaries, abortion

Based on Hocking 1997: Pitt 1997

\section{Genetically Modified Organisms (GMOs)}

These days, we come across more and more feed types and individual products in our daily life, for example, genetically modified ,such products have to be carefully examined from the safety point of view(Cencic and Krygier,2007). The associated risk is considered to be the unexpected consequences of inserting foreign DNA into genome of a plant or animal (Kleiter et al., 2001). The potential hazards associated with GMOs in edible tissues of products from aquaculture include allergies, increased toxicity, increased cancer risks and changed nutrient levels (Kleiter et al., 2001).

\begin{abstract}
Risk to human health
With the increased use of veterinary drugs in food production, there is global concern about the consumption of low levels of antimicrobial residues in aquatic foods and the effects of these residues on human health. The potential hazards associated with the presence of antimicrobial drug residues and GMOs in edible tissues of products from aquaculture include allergies, increased toxicity, changes in colonization patterns of human-gut flora and acquisition of drug resistance in pathogens in the human body (WHO, 1999),increased cancer risks and changed nutrient levels (Kleiter et al.,2001).
\end{abstract}

Table 2. Principal risks associated with food and feed safety issues

\section{Priority of Risk \\ (a) Spread of disease through} use of animal material in feed

\section{Description of Risk}

- The BSE epidemic has shown that infective material in feed can spread animal disease with important public health consequences. Only small amounts are necessary for disease to take hold

(b) Contaminants and other undesirable substances in feed (e.g. heavy metals, dioxins and PCBs, mycotoxins)

(c) Use of medicines and zootechnical additives, including coccidiostats and antibiotic growth promoters (AGPs), in feed.

(d) Salmonella and other microbiological risks.
Risks to consumers are mostly longterm (chronic) via carry-over into animal produce. Primary risk is of gross contamination through a specific incident (see Annex II for previous intstances).

Threat via residues in meat. Such use is one of factors, although not the largest, in conferring antibiotic resistance to humans.

Salmonella and other zoonoses (animal diseases communicable to man) in animal feed can be conveyed in food. Potential risk from possible novel zoonoses

\section{Action taken/proposed}

- UK ban on mammalian meat and bone meal (MBM) since 1996.

- Food industry and supermarkets specifying that animal material be removed from feed

- EC ban on processed animal protein.

- Catering waste: UK bank on swillfeeding, plus EC proposed bans on catering waste.

- Risk-based assurance arrangements via industry and legal control.

- Maximum permitted levels in law for heavy metals, mycotoxins, pesticide residues, botanical contaminants.

- Recent bans on 7 AGPs, with remaining 4 under close review. Commission committed to phasing these out

- National and EC authorization mechanisms for veterinary medicines and zootechnical additives.

- Monitoring for veterinary resides.

- Industry action via better practice, and use of heat and chemical treatments.

- Widespread monitoring and published results.

- Proposed EC directive on zoonoses. 
(e) Use of non-medicinal additives in feed.

(f) Use of inappropriate materials in feed.

(g) Genetically modified organisms and derived materials in feed.
Despite stringent authorization mechanisms for new additives risks could arise through loopholes in categorization and lack of review of existing approved additives.

Despite list of banned materials, European Parliament and others are pressing for a positive (exclusive) list of what can be used in feed.

Despite being subject to authorization, GMOs are of concern to consumers especially through use of imported GM materials. Major supermarkets and others are seeking to avoid feed containing GM macro ingredients
- Commission working on consolidated and revised Regulation based on Member States' views.

- Expected to involve review of existing additives and of use of vitamins, trace elements etc. via non-feed routes.

- Feasibility study being conducted on prospects for positive list.

- Rigorous official assessment procedures including role for ACAF.

- EC proposal covering authorization and labeling of GM feeds under discussion. Stakeholders consulted.

Source: EFSA (2003)

\section{CONCLUSION}

However, the principal steps to avoid problems are awareness of all the potential vulnerable points in production and handling of feed and raw materials and taking of appropriate action to address these. Having identified the main threats and risks through pathogenic, chemical or naturally occurring contaminants and through industry practices, it should be noted that a raft of legislation should be in place. Aim should be increased safeguards against bad practice leading to feed contamination. Inspection of imported feed ingredients is also very necessary.

Hazard analysis and critical control point (HACCP) system for feed processing like those already in place for animal processing would make feed manufacturers spell out where contamination may occur during processing, then build in procedures to prevent it.

\section{REFERENCES}

Cencic, A. and K. Kriggier (2007) Miscellaneous hazards In: Luning, P.A., Devlieghere, F. and Verhe, R. (Eds.) Safety in the agric-food chain. Wageningen Academic publishers, the Netherlands pp.223248.
DeMeulenaer, B. (2007) Chemical hazards In: Luning, P.A., Devlieghere, F. and Verhe, R. (Eds.) Safety in the agric-food chain. Wageningen Academic publishers, the Netherlands pp.145-208

D'Aoust, J.Y. (2000) Salmonella. In: Lund, B.M., T.C. Baird-Parker and G.W. Gould (eds). The microbiological Safety and Quality of foods. Aspen, Gaithersberg, Maryland, USA. Pp.1233-1299.

CAC (Codex Alimentarius Commission) (2001). Food Hygiene Basic Texts. $2^{\text {nd }}$ ed. Food and Agriculture Organization/World Health Organization, Rome, Italy.

EC. (European Commission) (2001b). Commission Decision 2001/699/EC Concerning certain protective measures with regard to certain fishery and aquaculture products intended for human consumption and originating in China and Vietnam. Official Journal of the European Communities L125.pp.11-12.

EC. (European Commission) (2001b). Commission Decision 2001/705/EC Concerning certain protective measures with regard to certain protective measure with regard to certain fishery and aquaculture products intended for 
human consumption and originating in Indonesia. Official
Journal of the European Communities. L.260, pp.35-36.

WHO (World health Organization) (1999). Joint FAO/NACA/WHO Study Group on Food safety issues associated with products from aquaculture, WHO Technical Report Series No. 883. World Health Organization, Geneva, Switzerland.

Ahmed, F.E. (ed) (1991). Seafood safety, National Academy Pres. Washington DC, USA.

Little, D.C. and P. Edwards (2003). Integrated Livestock fish farming systems. Inland Water Resources and Aquaculture Service, FAO. $189 \mathrm{pg}$.

EFSA (European Food Standard Agency) (2003). Animal Feeds-Risks to Food Safety, Agenda Item 5. FSA/01/07/03. Fish Feed 4. pdf. White Paper the Food Standards Agency.

Pitt, J.I. (1997). Toxigenic species of Penicillium. In: Doyle, M.P., Beuchat, L., Montville, T.J. (Eds.), Food Microbiology, Fundamentals and Frontiers. ASM Press, Washington, D.C., pp.427-439.

Hocking, A.D., (1997). Toxiogenic Species of Aspergillus In: Doyle, M.P., Buchat, L., Montville, T.J. (Eds.), Food Microbiology. Fundamentals and Frontiers. ASM Press, Washington, D.C., pp.413425. 